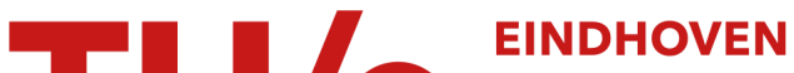 UNIVERSITY OF TECHNOLOGY
}

\section{Magnetic permeability behavior in single crystal Mn-ferrites}

Citation for published version (APA):

Simsa, Z., Zounova, F., \& Brabers, V. A. M. (1988). Magnetic permeability behavior in single crystal Mn-ferrites. IEEE Transactions on Magnetics, 24(2, Pt. 2), 1841-1843. https://doi.org/10.1109/20.11620

DOI:

$10.1109 / 20.11620$

Document status and date:

Published: 01/01/1988

\section{Document Version:}

Publisher's PDF, also known as Version of Record (includes final page, issue and volume numbers)

\section{Please check the document version of this publication:}

- A submitted manuscript is the version of the article upon submission and before peer-review. There can be important differences between the submitted version and the official published version of record. People interested in the research are advised to contact the author for the final version of the publication, or visit the $\mathrm{DOI}$ to the publisher's website.

- The final author version and the galley proof are versions of the publication after peer review.

- The final published version features the final layout of the paper including the volume, issue and page numbers.

Link to publication

\section{General rights}

Copyright and moral rights for the publications made accessible in the public portal are retained by the authors and/or other copyright owners and it is a condition of accessing publications that users recognise and abide by the legal requirements associated with these rights.

- Users may download and print one copy of any publication from the public portal for the purpose of private study or research.

- You may not further distribute the material or use it for any profit-making activity or commercial gain

- You may freely distribute the URL identifying the publication in the public portal.

If the publication is distributed under the terms of Article 25fa of the Dutch Copyright Act, indicated by the "Taverne" license above, please follow below link for the End User Agreement:

www.tue.nl/taverne

Take down policy

If you believe that this document breaches copyright please contact us at:

openaccess@tue.nl

providing details and we will investigate your claim. 
MAGNETIC PERMEABILITY BEHAVIOUR IN SINGLE CRYSTAL MR-FERRITES

\author{
Z. Simša, F. Zounová and V.A.M. Brabers (1)
}

Institute of Physics, Czechoslovak Acad. Sci., 18040 Prague 8, Czechoslovakia

(1) Dept. of Physics, Technical University, 5600 MB Eindhoven, The Netherlands

Measurements of the initial permeability $\mu$ of sintw crystal ferrites $\mathrm{Mn}_{\mathrm{x}} \mathrm{He}_{3}-\mathrm{x}_{4}$ with $0<x<1.25$ are performed at audio frequencies at temperatures from 10 to $550 \mathrm{~K}$. Large disporsionless changes in $\mu$ occur near the Verwey transition of magnetite whereas two relaxation type anomalies are observed at $40 \mathrm{~K}$ and $80 \mathrm{~K}$. Similar anomalies are fourd at $20 \mathrm{~K}$ and $60 \mathrm{~K}$ for the $x=0.5$ sample. They are followed by a boad feature persisting up to room temperature. The main relaxation processes in the case of samples containing larger amounts of manganese occur above $100 \mathrm{~K}$ ard shift to higher temperatures with the increase of $x$. The activation enereites determinod for particular processes indicate the olectronio origin of these effects.

\section{Introduction}

The initial permeability of magnetio materials, $\mu-\mu \cdots, j \mu$, relates directiy to tho movemant of the domain witlo and to the r... laxation processes encountered in the samples studied. The observed relaxation processes in ferrites appear to be mostly of electronic or of ionic character. They manifest themselves ir a variety of measured phenomomena as e.g. a isaceomotation of perineability, induced anisutropy and magnetic losses (for reviews wo $\ldots g .(1.6\})$. Only few papers were devoted to the iritial permeability measurements on sitigle erysta]s, Biokford [7] ascribed the aromalous behaviour of $\mu$ near $120 \mathrm{~K}$ in single cryatals of magnetite to both the crystallographio phase transition (Verwey transition and to the passage of the magneto crystalline anisotropy constant $\mathrm{K}_{1}$ through zer. at ' $\mathrm{t} k$. On the ot $]_{\mathrm{k}} \mathrm{r}$ hand, Enz [8] argued that the maximat of a below room temperature in some $\mathrm{Mn}$ and $\mathrm{Mn}-\mathrm{Zn}$ ferrites were due to disanomodalion phenonena. However, ohta [9] demonstrated that the second maxima in $\mu$ in the oy:tem of Mr $7 / n$ ferrites are primarily caused at $k_{1}=0$ whereas the disaccomodations bring abult only smal] temperatiare shiftr.

It setmed wothwhile to irvestigate the behavion ref the injtial permeability of Mriferrite single crystals over a broad temperature range and to find out the min underlyine mochaniems responsible for the observed anomal jer

\section{Fyerimental part}

Samples. Gingla oryolials in the ferrjte system $\mathrm{Mn}_{\mathrm{F}} \mathrm{F}_{3} \mathrm{O} 4+\gamma$ were prepared hy a travelling molten tone techinique as desoribed elsewher [10]. After the erowth prooss the singlo aryatals wore whitionally beat treatal in writrolled atmospheres to impersos thmograjty ant to reljeve mochanjeal stress. The final chemiral eompositions as well is come sther sample parameter ase givan in Trable 1 From cylindrical rods the toroil

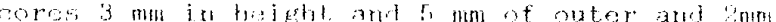
of inurer dimcter wore tube-bored with the holo of gerintire purder Bnfore the appropriate wisuling was pui on the samplas were etohed to remove the damaged surfans.
Table 1

Parameters of $\mathrm{Mn}_{\mathrm{x}} \mathrm{Fe}_{3-\mathrm{x}} \mathrm{O}_{4+\gamma}$ crystals

\begin{tabular}{|c|c|c|c|c|c|}
\hline Sample & $x$ & $\gamma$ & $\begin{array}{l}\text { toroid } \\
\text { plane }\end{array}$ & $\mathrm{T}_{\mathrm{C}}(\mathrm{K})$ & $\mathrm{T}_{\mathrm{k}}(\mathrm{K}$ \\
\hline 1 & 0 & 0.00 & & 858 & 12 \\
\hline 2 & 0.52 & 0.0 & & 74 & 34 \\
\hline 3 & 0.95 & 0.0 & & 56 & 3 \\
\hline 4 & 1.10 & 0.004 & & 54 & $>40$ \\
\hline 5 & 1.25 & -0.011 & $100)$ & 527 & $>40$ \\
\hline
\end{tabular}

Method. To determine real and imaginary parts of the permeability of toroidal ferrite samples, the two-coil method described earlier [11] was used. Using the internal built-in oscillator for the ac driving field in the 100 $\mathrm{Hz}$ to $10 \mathrm{kHz}$ frequency region a Two Phase Lock-in Analyzer EG\&G mode1 5206 served for the measurements of both the in-phase and quadrature components of a signal induced in the secondary coil. In order to measure the true initial permeability values in the Reyleigh region of the magnetisation curve, the amplitudes of the magnetic driving fields were kept below $1 \mathrm{~A} / \mathrm{m}(<10 \mathrm{mOe})$. Low temperature measurements were realized using a liquid helium continuous-flow cryostat; higher temperatures were attained in a furnace. More details about the method and the set-up used can be found in [11].

Results. In Figs. 1 to 5 , the temperature dependences of the real and imaginary parts of the initial permeability measured at $1 \mathrm{kHz}$ are represented. All samples were first heated above their Curie temperatures $\mathrm{T}_{\mathrm{C}}$ to attain demagnetized state. Curves in Figs. 1 to 5 were then obtained by measuring $\mu$ in decreasing temperatures. The high-temperatures behaviour of $\mu$ " and $\mu$ "indicates tre preserice of the maxima in $\mu$ occuring just below the Curie temperatures [12].

In magnetite (see the right hand part of Fig.1) the other maximum lies near the verwey transition temperature, $T_{\mathrm{v}}=121 \mathrm{~K}$. A more

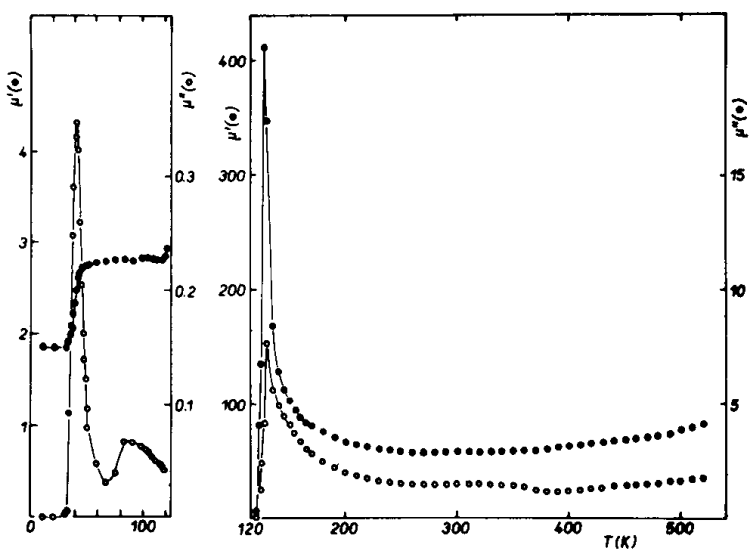

Fig 1 Temprature dependences of the real $\left(\mu^{\prime}\right)$ and the imaginary ( $\left.\mu^{\prime \prime}\right)$ parts of the initial permeability of magnetite (sample 1 ). 


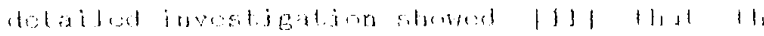

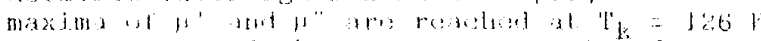

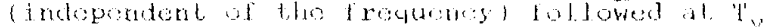

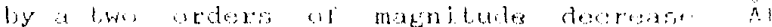
still lower temperatures 1 ses the 1ell tom

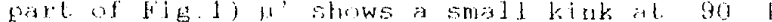
loblowad by a sharp decrease near $40 \mathrm{k}$. Al. l.he sane tomperatures $1{ }^{\prime \prime}$ passes throukh maxima: a small and broal one at $90 \mathrm{~K}$ and a sharp ore al 40 K. Both maxima are frequency dependent, printing out the presence of relaxations.

Sampla $\therefore(x .0 .52)$ displays a somewhet similar bohaviour "see Fig. 2a. After passing the higl lemperature maxima just below ' ${ }^{\circ} \mathrm{C}$ both components of $\mu$ display a second narrow disperionloss maximum rear $340 \mathrm{~K}$ followed by broad featums persistint to low temperatures. other sticip maximum and a shoulder in $\mu^{\prime \prime}$, both frequeruy dependent, may be observed (see the arrows in lig. 2a) at $20 \mathrm{~K}$ and $60 \mathrm{~K}$ respectively.
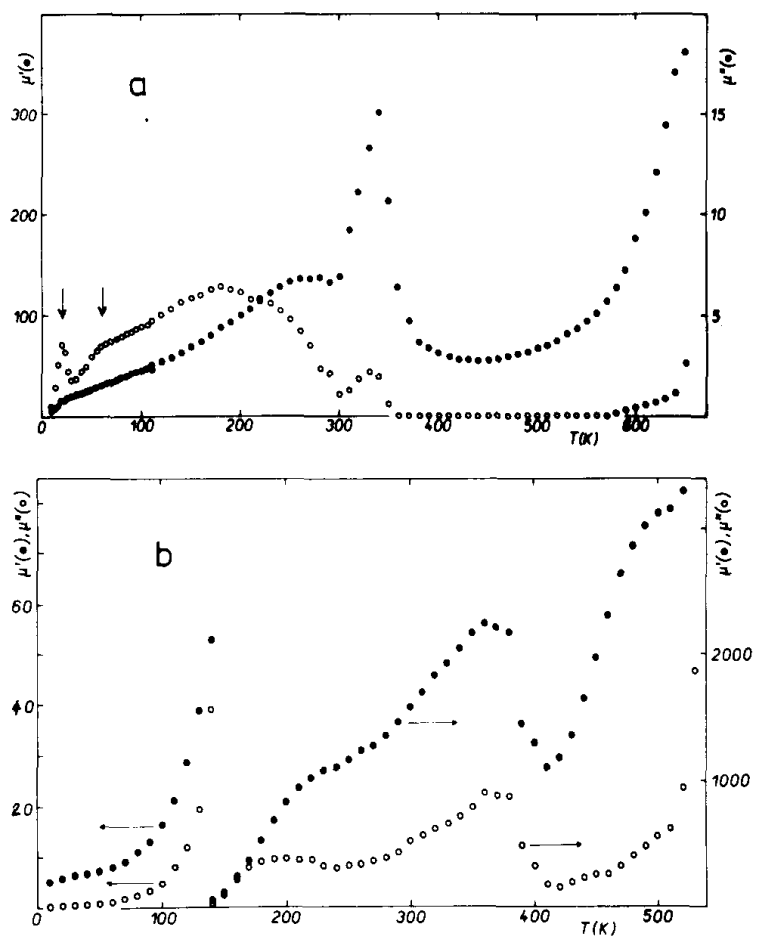

f'ie. 2a, t). 'Temporatore dependences of the real and tho juajinary parts of the initial permobility of the sample $4(a)$ and $3(b)$. See lable 1 tor sample details.

Cro poak and two shoulders in the toniperature dopendences of 1 for sample 3 $(x-0 . y 5)$ are socr in Fig. $2 b$. Shold dere at 200 $k$ and bor k shitt with frequeroy while the maximum near $360 \mathrm{~K}$ is fourd to be frequency indoperdent wheres its magnitude appeares to be time deprentent.

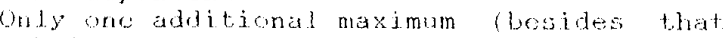
just lw: l.w ll.) war be roongniat in the temperature legrenderse of 11 of samples $A$ all 5 seo fie 3it, h. Tho maxima in bath sanpli:n

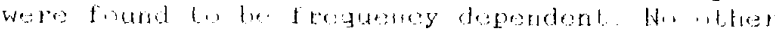
aromalies wexe found in the tomperathre

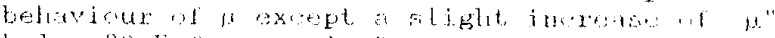
below $30 \mathrm{k}$ lor sumple b
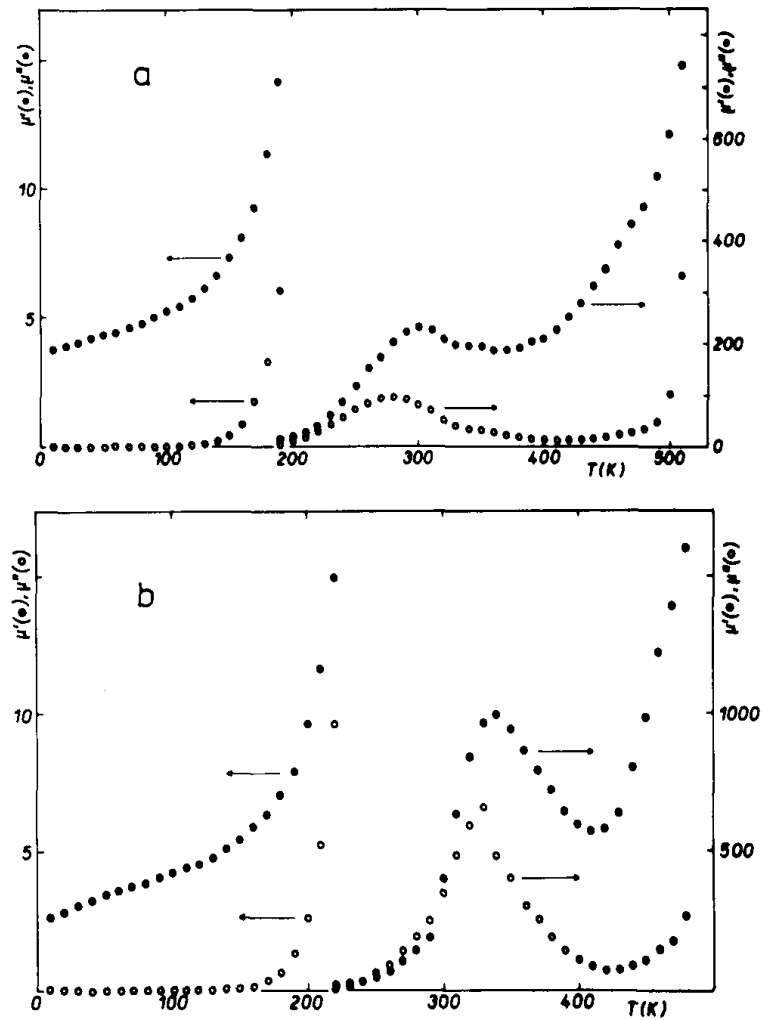

Fig. 3a,b. 'lemperature dependences of the real and the imaginary parts of the initial permeability of the sample 4(a) and 5(b). See Table 1 for sample details.

\section{Discusㅗ하요므}

Initial permeability behaviour. The increase of the initial permeability near $T_{C}$ (1.e. the primary maximum) is well described $[1,2]$. More interesting is the occurrence of the second maximum in $\mu$ at temperatures well below $\mathrm{T}_{\mathrm{C}}$.

One of the possible reasons is the passing of the anisotropy constant $K_{1}$ through zero. Sharp maxima in $\mu^{\prime}$ and $\mu^{\prime \prime}$ in magnetite ( sample 1 ) near I'v could indeed be concelved in terms of $\mathrm{K}_{1}=0$ occurring at $\mathrm{T}_{\mathrm{k}}=126 \mathrm{~K}[7]$. However, the steep decrease by two orders of magnitude is more likely to be connected with the crystallographic and magnetic transition occurring at $\mathrm{T}_{\mathrm{V}}=121 \mathrm{~K}$. The two other anomalies below $\mathrm{T}_{\mathrm{V}}$ have a quite different character and cannot be explained by supposing $K_{1}=0$.

In the case of sample $2 \quad(x=0.52)$, sharp maxima near $340 \mathrm{~K}$ are also in agreement with the estimated temperature range for $k_{1}=0$

values [14]. The same type of explanation is also valid in the case of sample $3 \quad(x=0.95)$ where the extrapolated temperature for $\mathrm{K}_{1}=0$ is about $370 \mathrm{~K}$ [14] in good agreement with the observed dispersionless maxima of $\mu$ at $360 \mathrm{~K}$. The broad shoulder in $\mu$ ' and a maximum in $\mu$ "below $200 \mathrm{~K}$ have obviously a different, frequency dependent character.

No reliabla data on the high temperature bohaviour of $K_{1}$ in manganese-rich part of tho system are ayailable. The extrapolatior following $[14]$ would yield $\mathrm{T}_{\mathrm{k}}$ approaching $\mathrm{T}_{\mathrm{C}}$. 
